\title{
Farklı Toprak Bünyelerinde Sulama Suyu Bor Düzeylerinin Fasulye Bitkisi Verimi Üzerine Etkilerinin Belirlenmesi
}

\author{
Aysun CÖMERT ${ }^{1}$, Sema KALE ÇELIi ${ }^{2} *$ \\ ${ }^{1}$ Gıda Tarım ve Hayvancılık Bakanlığı, Eğirdir Tarım İlçe Müdürlüğü [ORCID ID: http://orcid.org/0000- \\ 0002-2664-175X] \\ ${ }^{2}$ Süleyman Demirel Üniversitesi, Ziraat Fakültesi, Tarımsal Yapılar ve Sulama Bölümü, Isparta \\ [ORCID ID: http://orcid.org/0000-0001-8161-276X] \\ * Sorumlu yazar: semakale@sdu.edu.tr
}

\begin{abstract}
Öz
Bu çalışma farklı toprak bünyelerinde yetiştirilen fasulye bitkisinde, değişik konsantrasyonlarda uygulanan sulama suyu bor (B) düzeylerinin bitki verim (yaş ve kuru ağırlık olarak) üzerine etkilerinin belirlenmesi amaçlanmıştır. Çalışma, aynı $B$ düzeyine sahip sularının ağır veya hafif bünyeli topraklarda kullanılması durumunda ortaya çıkacak farklılıkları incelemek amacıyla saksı denemeleri şeklinde serada yürütülmüştür. Araştırmada deneme konularını; kumlu ve killi olmak üzere iki farklı toprak bünyesi ve $B_{0} ; 0 \mathrm{ppm}, \mathrm{B}_{1} ; 0.5 \mathrm{ppm}, \mathrm{B}_{2} ; 1.0 \mathrm{ppm}, \mathrm{B}_{3} ; 2.0 \mathrm{ppm}, \mathrm{B}_{4} ; 3.0 \mathrm{ppm}, \mathrm{B}_{5} ; 5.0 \mathrm{ppm}$ olmak üzere 6 farklı $\mathrm{B}$ konsantrasyonu içeren sulama suyu oluşturmuştur. Araştırma sonuçlarına göre; her iki toprak bünyesi için en yüksek bitki yaş ve kuru ağılık değeri $B_{2}(1 \mathrm{ppm})$ konusundan elde edilirken en düşük değerler ise $B_{5}(5 \mathrm{ppm})$ konusundan elde edilmiştir. Toprak bünyeleri açısından uygulanan $B$ seviyelerinin etkileri karşılaştıııldı̆ıında fasulye bitkisinin kumlu toprakta daha iyi gelişme gösterdiği görülmüştür. Bu nedenle kumlu toprakta elde edilen bitki yaş ağırlığı değeri \% 17-31 arasında ve kuru ağırlığında \% 18-23 arasında killi toprakta elde edilen değerlere göre daha yüksek bulunmuştur. Ancak; toprak bünyelerine göre uygulanan $B$ düzeylerinin kontrol konusuna göre oransal farkları incelendiğinde özellikle $B_{4}$ ve $B_{5}$ konularında kumlu topraklarda bitki gelişimi üzerine B zararının, killi topraklara oranla $\% 40$ daha fazla olduğu bulunmuştur. Her toprak bünyesi için bitkinin B eşik değeri 1 ppm olarak saptanmıştır. Eşik değerini aşan yüksek borlu suların kumlu topraklar yerine killi topraklarda kullanılması önerilebilir.
\end{abstract}

Anahtar Kelimeler: Bor, Fasulye, Sulama suyu, Toprak bünyesi

\section{Determination of Effects on Bean Yield of Irrigation Water Boron Level under Different Soil Textures}

\begin{abstract}
The aim of this study was to evaluate effects of different irrigation water boron (B) concentration on bean wet (fresh) and dry weights. The study was carried out in the pot experiments in order to determine the differences that would arise if the same B level waters were used in heavy or light textured soils. The treatments were; two different soil texture (sandy and clay) and 6 different B concentrations; $B_{0} ; 0$ ppm, $B_{1} ; 0.5$ ppm, $B_{2} ; 1.0$ ppm, $B_{3} ; 2.0$ ppm, $B_{4} ; 3.0$ ppm, $B_{5} ; 5.0$ ppm. According to the results; the highest plant fresh and dry weights for both soil types were obtained from $B_{2}(1 \mathrm{ppm})$ treatment while the lowest were at $B_{5}(5 \mathrm{ppm})$. When the effects of the $B$ levels applied in terms of soil texture were compared, it was seen that the bean grown better development in sandy soil. For this reason, fresh weight obtained from sandy soil was between $17 \%$ and $31 \%$ and dry weight was between $18 \%$ and $23 \%$, which was higher than clay soil. But when the proportional differences of the applied B levels according to the soil texture was examined, it was found that the $B$ damage on the plant growth in the sandy soil in $B_{4}$ and $B_{5}$ treatments was $40 \%$ higher than the clay soil. For each soil type, the $B$ threshold of the plant was determined as $1 \mathrm{ppm}$. It may be advisable to use high boron waters exceeding the threshold value in clay soils instead of sandy soils.
\end{abstract}

Key Words: Bean, Boron, Irrigation water, Soil texture 
Giriş

Dünyanın geleceği açısından vazgeçilmez bir unsur olan temiz su kaynakları gün geçtikçe kirlenmekte ve azalmaktadır. Özellikle kurak ve yarı kurak bölgelerde kıt su kaynakları tarımsal açıdan üretimi sınırlandıran en önemli parametredir. Son yıllarda azalan iyi su kaynaklarına alternatif olarak düşük kalitedeki suların sulamada kullanılması kaçınılmaz hale gelmiştir. Düşük kaliteli sulama sularında tuz, sodyum veya bor elementinin yüksek miktarlarda bulunması muhtemeldir. Tarım alanlarındaki topraklarda bor birikimi, sulama sularının içerdiği bordan ileri gelmektedir. Genel olarak doğal suların B içeriği oldukça düşüktür (0.3-1 ppm) (Ayyıldız, 1992). Ancak bor cevherinin üretimi esnasında ortaya çıkan atık suların doğrudan akarsulara verilmesi veya yeraltı suyuna sızması gibi nedenlerden yüzey ve yeraltı suyu bor kirliliği ortaya çıkmaktadır. Sulama sularındaki B düzeyinin fazlalığı bitkiler için son derece zararlıdır. Toprakta veya sulama suyundaki B derişimin belirli sınırları aşması durumunda bitki yaprağında sararma, yanma ve yarılmalar, olgunlaşmış yapraklarda dökülme ve büyüme hızının yavaşlaması ile üründe verimin azaldığı gözlenmektedir (Demirtaş, 2005). Bitki bünyesinde B hareketli olmayıp ancak belli bir kısmı kullanılmaya elverişlidir. $\mathrm{Bu}$ nedenle bitki gelişmesi için çeşitli periyodlarda topraktan B almak durumundadır. $B$ bitkiler için önemli bir besin maddesi olmasına rağmen, birçok bitki için topraktaki konsantrasyonu $4.0 \mathrm{mg} \mathrm{L^{-1 } y \mathrm { yi }}$ geçtiği takdirde bu kez $\mathrm{B}$, bitkisel üretimi azaltabilecek zararlara neden olmaktadır (Güngör ve Erözel 1994).

Bitkilerde B alımına etki eden faktörler $\mathrm{pH}$, toprak bünyesi, nem, sıcaklık, organik madde ve kil mineralleridir. Çözünebilir $B$ konsantrasyonu ve bitkiler tarafından B alımı hafif bünyeli topraklarda ağır bünyeli topraklara oranla daha fazladır (Wear ve Patterson, 1962). Toprakta absorbe edilen B seviyesi ise büyük ölçüde toprak bünyesine ve toprak çözeltisinin $\mathrm{pH}$ sına bağlıdır. Bu da artan kil içeriği ile birlikte artmaktadır (Bhatnager ve ark., 1979; Wild ve Mazaheri, 1979; Mezuman ve Keren, 1981; Elrashidi ve O'Connor, 1982).

Bu çalışmada kumlu ve killi bünyeye sahip iki farklı toprak bünyesinde yetiştirilen fasulye bitkisinin değişik düzeylerde bor içeren sulama suyuyla sulanması durumunda bitki gelişim ve veriminde ortaya çıkacak farklılıklar incelenmiştir. Ayrıca uygulanan borlu sulama suyunun her bir toprak bünyesinde oluşturduğu bor düzeyleri için izin verilen bor eşik değerleri belirlenmiştir.

\section{Materyal ve Metot}

$\mathrm{Bu}$ araştırma Isparta koşullarında Süleyman Demirel Üniversitesi Tarımsal Araştırma ve Uygulama Merkezi arazisinde bulunan plastik serada saksı denemesi şeklinde yürütülmüştür. Denemede çapı 17 $\mathrm{cm}$, yüksekliği $18 \mathrm{~cm}$ olan plastik saksılar kullanılmıştır.

Çalışmada, biri kontrol olmak üzere altı farklı düzeyde bor konsantrasyonu değerleri $\left(B_{0}=0\right.$ ppm, $B_{1}=0.5$ ppm, $B_{2}=1.0$ ppm, $B_{3}=2.0$ ppm, $B_{4}=3.0 \mathrm{ppm}, B_{5}=5.0 \mathrm{ppm}$ ) ve iki farklı toprak bünyesi ( $T_{1}=$ hafif; Kumlu ve $T_{2}=$ Ağır; Killi) deneme konusu olarak seçilmiştir. Araştırma 6 değişik bor seviyesinin 3 tekrarlamalı olarak denendiği tesadüf parselleri deneme deseninde göre 2 ayrı deneme olacak şekilde kurulmuştur. Denemede kullanılan toprak özellikleri Çizelge 1 'de verilmiştir. 
Çizelge 1. Deneme toprağının bazı fiziksel ve kimyasal özellikleri

Table 1. Some physical and chemical properties of experimental soil

\begin{tabular}{lll}
\hline $\begin{array}{l}\text { Toprak parametreleri } \\
\text { (Soil paremeters) }\end{array}$ & $\begin{array}{l}\mathbf{T}_{\mathbf{1}} \text { (Hafif bünyeli toprak) } \\
\text { (Light textured soil) }\end{array}$ & $\begin{array}{c}\mathbf{T}_{\mathbf{2}} \text { (Ağır bünyeli toprak) } \\
\text { (Heavy textured soil) }\end{array}$ \\
\hline \% Kum (Sand \%) & 92.96 & 18.89 \\
\% Kil (Clay \%) & 1.64 & 52.80 \\
\% Silt (Silty \%) & 5.4 & 28.31 \\
Bünye Sınıfı ( Texture Class) & Kum (S) Sand & Kil (C) Clay \\
EC (dS m ${ }^{-1}$ ) & 0.48 & 0.49 \\
pH & 6.75 & 7.10 \\
\% Kireç (Lime \%) & 0.37 & 0.7 \\
Tarla kapasitesi (Field capacity) & 10.03 & 34.52 \\
Solma noktası (Wilting point) & 3.70 & 23.29 \\
\hline
\end{tabular}

Çalışmada sırık fasulye olan Alman Ayşe (Phaseolus vulgaris) fasulye çeşidi kullanılmıştır. Fasulye tohumları 20.06.2013 tarihinde her saksı başına 9 adet olarak $3 \mathrm{~cm}$ derinliğe ekilmiştir.

Ekimden hemen sonra saksılara tarla kapasitesine çıkacak kadar sulama suyu verilmiştir. Fasulye tohumlarının ekiminden sonra çıkışlar tamamlanana kadar çeşme suyu uygulanmış ve her bir saksıda bitki sayısı 3 adet olacak şekilde seyreltme yapılmıştır. Deneme başlangıcında $10 \mathrm{ml} \mathrm{NPK}$ gübresi (\%3.5 $\mathrm{NH}_{4}, \% 5.5 \mathrm{NO}_{3}, \% 10$ Üre, 19N19P-19K+Mikro elementler) her bir saksıya süspansiyon halinde uygulanmıştır. Gübrenin diğer yarısı da bitki çıkışları tamamlandıktan sonra uygulanmıştır. Her bir saksı günlük düzenli bir şekilde tartılmış ve saksı ağırlığındaki azalmalara bağlı olarak su miktarları tarla kapasitesinin \% 50'sine düştüğünde konulara göre hazırlanan borlu sular ile sulanarak tarla kapasitesi düzeyine çıkarılmıştır. Denemede bitkiler 80 günlük gelişme periyodundan sonra kök hizasından kesilerek hasat edilmiştir. Hasat edilen bitki örnekleri konulara göre tartılıp yaş ağırlıkları alınmıştır. Yaş bitkiler üzeri delinen kese kağıtlarına konularak $65{ }^{\circ} \mathrm{C}^{\prime}$ lik fırında sabit ağırlığa gelinceye kadar kurutulmuş ve daha sonra kuru ağırıkları alınıp kaydedilmiştir (Tüzüner, 1990).
Deneme sonunda elde edilen veriler faktöriyel düzende MINITAB paket program aracılığı ile değerlendirilmiş ve sonuçlar Yurtsever (1984) tarafından verilen esaslara göre yorumlanmıştır.

\section{Araştırma Bulguları ve Tartışma}

Kumlu toprakta sulama suyu bor düzeyinin bitki yaş ve kuru ağırlığı üzerine etkisi

Kumlu toprakta denemede uygulanan sulama suyu bor düzeylerinde elde edilen ortalama bitki yaş ve kuru ağırlık değerleri Çizelge 2'de verilmiştir.

Çizelge 2. Kumlu topraklarda konularına göre ortalama bitki yaş ve kuru ağırlığı

Table 2. Average plant wet and dry weights according to treatments on sandy soils

\begin{tabular}{|c|c|c|}
\hline $\begin{array}{c}\text { Konular } \\
\text { (Treatments) }\end{array}$ & $\begin{array}{l}\text { Yaş ağırlık (gr } \\
\text { saksı }^{-1} \text { ) } \\
\text { Wet weight } \\
\left(\text { gr pot }^{-1}\right)\end{array}$ & $\begin{array}{l}\text { Kuru ağırlık } \\
\text { (gr saksı }^{-1} \text { ) } \\
\text { Dry weight } \\
\left(g_{p o t}{ }^{-1}\right)\end{array}$ \\
\hline $\mathrm{B}_{0}$ & 40.99 & 21.33 \\
\hline $\mathrm{B}_{1}$ & 41.36 & 21.54 \\
\hline $\mathrm{B}_{2}$ & 43.02 & 21.83 \\
\hline $\mathbf{B}_{3}$ & 41.13 & 21.69 \\
\hline $\mathrm{B}_{4}$ & 38.74 & 20.84 \\
\hline $\mathrm{B}_{5}$ & 29.78 & 19.67 \\
\hline
\end{tabular}

Araştırmada sulama suyu bor düzeyi ile bitki yaş ve kuru ağrılıkları arasında önemli 
düzeyde negatif yönde kuadratik bir ilişki söz konusudur. Determinasyon katsayısı $\left(R^{2}\right)$ yaş ağırlık ve kuru ağırlık için sırasıyla 0.98 ve 0.97 olarak bulunmuştur (Şekil 1).

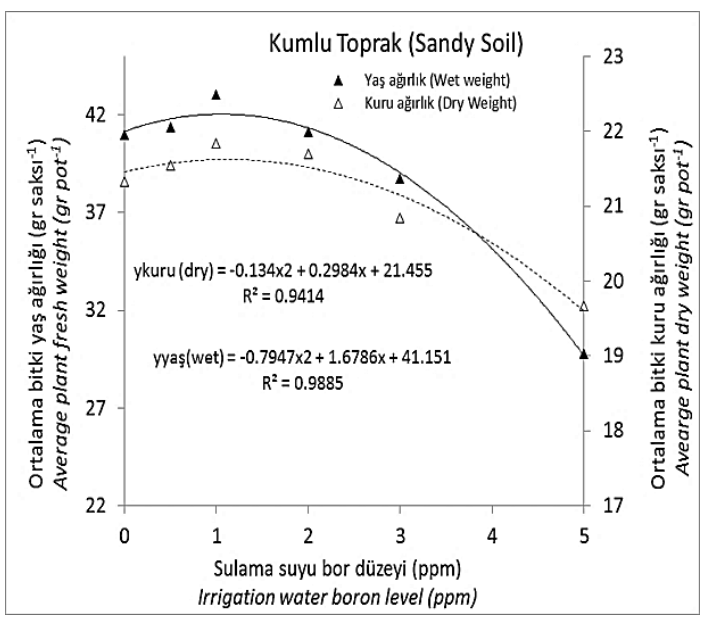

Şekil 1. Kumlu topraklarda sulama suyu bor düzeyi bitki yaş ve kuru ağırlık ilişkisi

Figure 1. Relationship between boron level and plant wet and dry weight on sandy soils

Yapılan varyans analizi sonucunda deneme konularında elde edilen yaş ağırık ortalamaları arasındaki farklar 0.05 düzeyinde önemli bulunurken kuru ağırlık değerleri arasında istatistiki bir farklılık ortaya çıkmamıştır. Tukey testine göre yaş ağırlıklar için elde edilen sınıflar Şekil 2'de verilmiştir.

Hiç bor uygulanmayan $B_{0}$ konusuna ait ortalama yaş ve kuru ağırlık değerleri baz alınarak hesaplanan oransal verim değerleri ve oransal farklar Şekil 3'de verilmiştir.

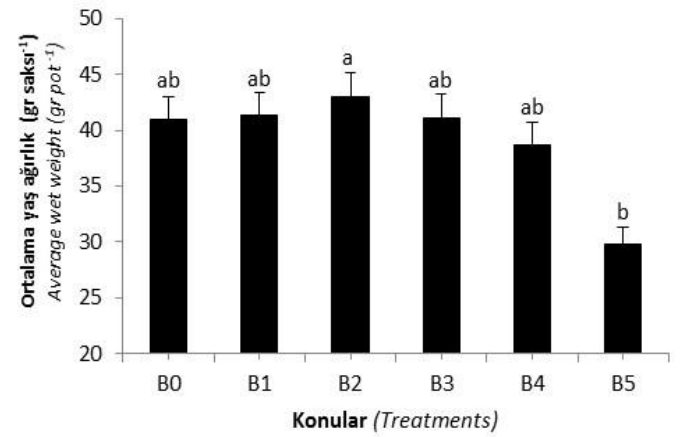

Şekil 2. Kumlu topraklarda uygulanan bor seviyelerinde bitki yaş ağırlık ortalamalarına göre Tukey testi sınıfları

Figure 2. Tukey test classes according to the plant fresh weight average in the boron levels applied in sandy soil

Denemede fasulye bitkisi yaş ağırlık verilerinde hiç bor uygulanmayan konuya göre 0.5 ppm B uygulanan konuda yaklaşık \%1'lik bir artış söz konusu iken 1 ppm ve 2 ppm'lik konularda sırasıyla yaklaşık $\% 5$ ve $\%$ 0.3 düzeyinde artış ortaya çıkmıştır. $3 \mathrm{ppm}$ ve $5 \mathrm{ppm}$ B içeren konularda ise yaklaşık \% 5.5 ve \% 27 düzeyinde azalma söz konusu olmuştur. Kuru ağırlık için ise oransal verim farkları $B_{0}, B_{1}, B_{2}, B_{3}$ konularında sırasıyla yaklaşık \% 1.0, \% 2.3, \% 1.7 artmış ve $B_{4}, B_{5}$ konularında $\% 2.3$ ve $\% 7.8$ düzeyinde azalmıştır. Genel olarak sulama suyu B değeri artıkça bitki veriminde önce oransal bir artma, 1 ppm'den sonra ise oransal bir azalmanın olduğunu görülmüştür. 

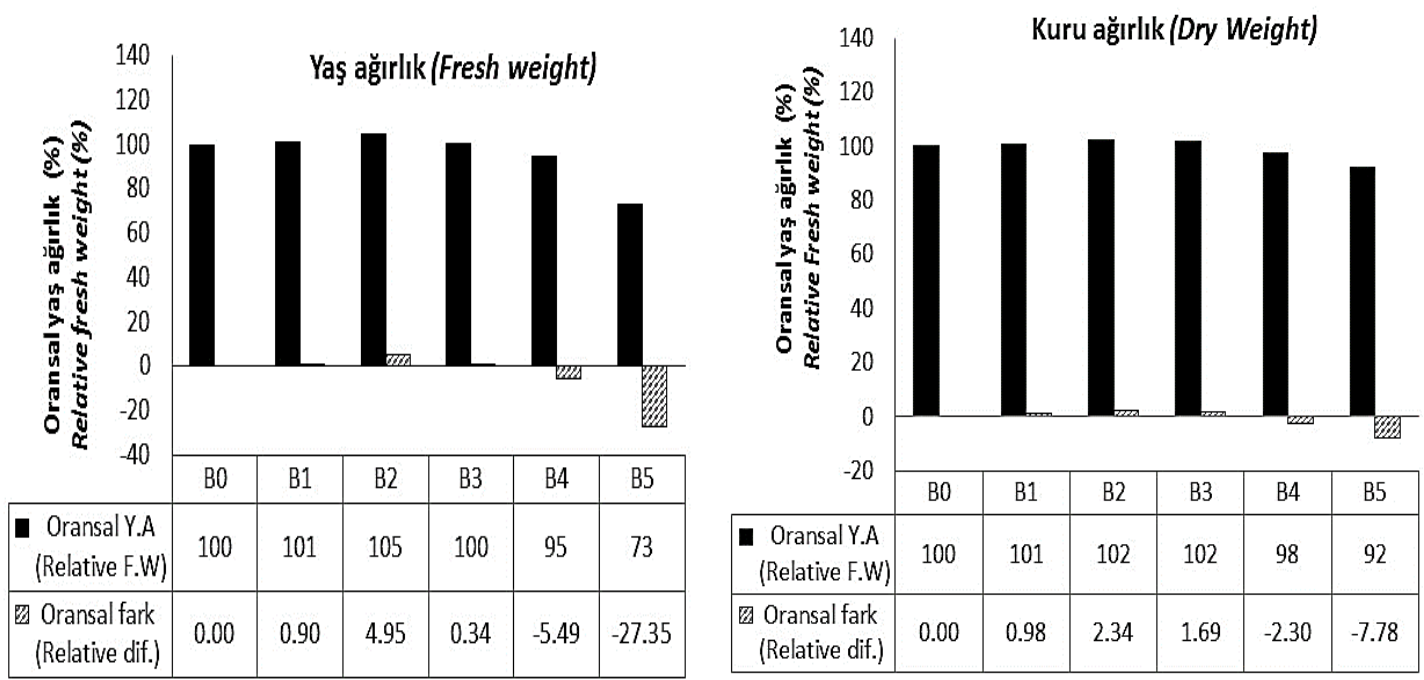

Şekil 3. Kumlu topraklarda oransal yaş ve kuru ağırlık değerleri ve farklar

Figure 3. Relative wet and dry weight values and differences in sandy soils

Killi Toprakta Sulama Suyu Bor Düzeyinin Bitki Yaş ve Kuru Ağırlıkları Üzerine Etkisi

Denemede killi topraklarda elde edilen ortalama bitki yaş ve kuru ağırlık değerleri Şekil 4'te verilmiştir.

Killi toprakta sulama suyu bor düzeyi ile bitki yaş ve kuru ağırlıkları arasında önemli düzeyde negatif yönde kuadratik bir ilişki söz konusudur. Determinasyon katsayısı $\left(R^{2}\right)$ yaş ağırlık ve kuru ağırlık için sırasıyla 0.98 ve 0.90 olarak bulunmuştur (Şekil 5).

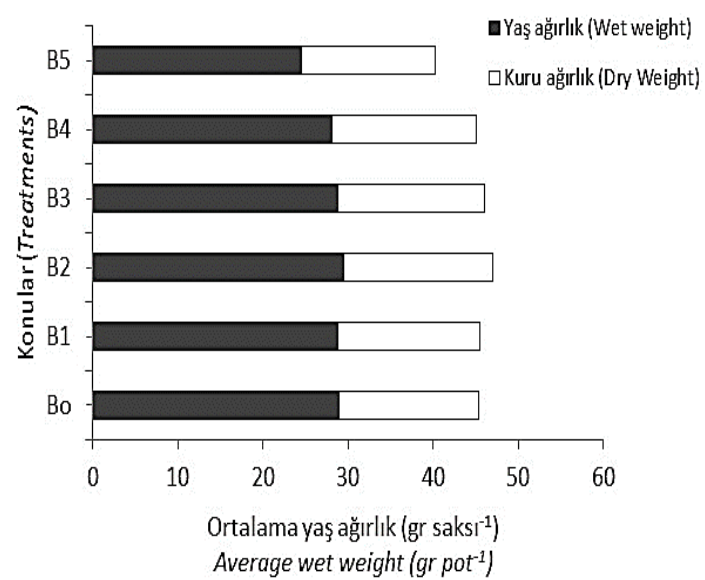

Şekil 4. Killi topraklardaki ortalama bitki yaş ve kuru ağırlık değerleri

Figure 4. Average plant wet weight and dry weight in clay soils

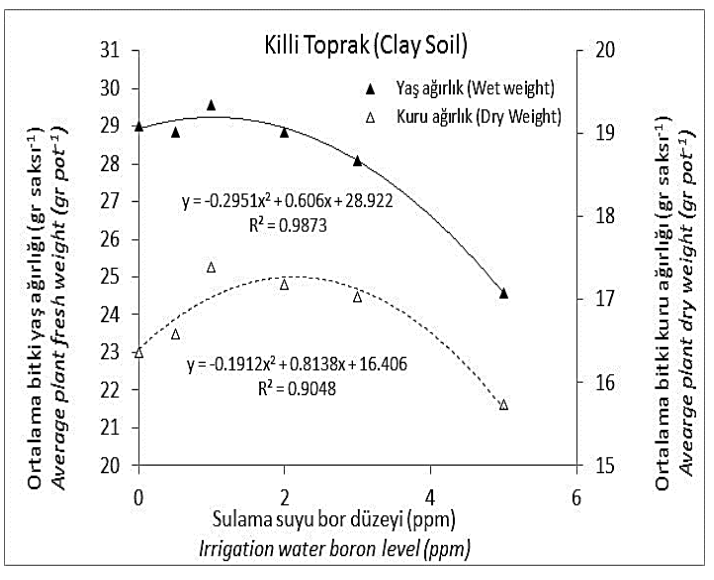

Şekil 5. Killi topraklarda sulama suyu bor düzeyi bitki yaş ve kuru ağırlık ilişkisi

Figure 5. Relationship between boron level and plant wet and dry weight on clay soils

Killi toprakta uygulanan bor düzeylerine göre elde edilen yaş ağılık miktarları arasındaki farklar 0.01 düzeyinde önemli çıkmasına rağmen kumlu topraklarda olduğu gibi kuru ağırlık miktarlarında konular arası fark önemli bulunmamıştır. $B_{\circ}$ konusuna ait ortalama yaş ve kuru ağırlık değerleri baz alınarak hesaplanan oransal verim değerleri ve oransal farklar Şekil 6 'da verilmiştir. 

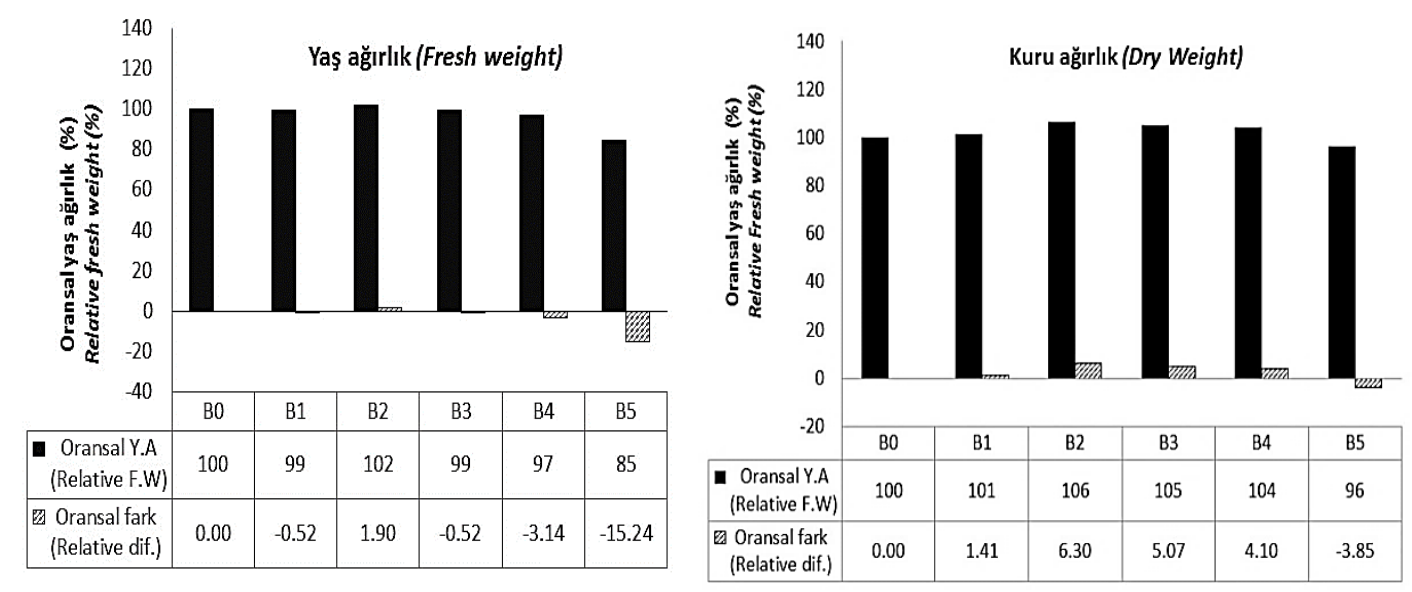

Şekil 6. Killi topraklarda oransal yaş ve kuru ağırlıklara göre ortaya çıkan oransal farklar

Figure 6. Relative wet and dry weight values and differences in clay soils

Çizelge 3. Killi topraklarda uygulanan bor seviyelerine göre bitki yaş ağırlık, kuru ağırlık değerlerine göre Tukey testi sınıflandırmaları

Table 3. Tukey test classes according to the plant fresh weight average in the boron levels applied in clay soil

\begin{tabular}{|c|c|c|c|c|c|c|}
\hline Konular (Treatments & $\mathbf{B}_{0}$ & $B_{1}$ & $B_{2}$ & $B_{3}$ & $B_{4}$ & $B_{5}$ \\
\hline Yaş Ăg. (Wet weight) & $29.00 \mathrm{~A}$ & $28.85 \mathrm{~A}$ & $29.55 \mathrm{~A}$ & $28.85 \mathrm{~A}$ & $28.00 \mathrm{AB}$ & $24.58 \mathrm{~B}$ \\
\hline Kuru Ağ. (Dry weight) & $16.37 \mathrm{~A}$ & $16.58 \mathrm{~A}$ & $17.39 \mathrm{~A}$ & $17.19 \mathrm{~A}$ & $17.04 \mathrm{~A}$ & $15.73 \mathrm{~A}$ \\
\hline
\end{tabular}

Killi topraklarda bor uygulanmayan konuya göre en yüksek ortalama yaş ağırlı̆ı̆ elde ettiğimiz 1 ppm $\left(B_{2}\right)$ bor uygulanan konu yaklaşık \% 2'lik bir artı̧s söz konusu iken 2 ppm, 3 ppm ve 5 ppm lik konularda sırasıyla yaklaşık \% 0.5, \% 3.1 ve \%15 düzeyinde azalma ortaya çıkmıştır. Kuru ağırlık değerleri için ise oransal kuru ağırlık farkları 0 ppm uygulanan konulara göre sırasıyla \% 1.41, \% 6.30, \% 5.07 ve \% 4.10 artmış ve \% 3.85 düzeyinde azalmıştır. Kuru ağırlıktaki azalma yüzdeleri yaş ağırlığa oranla daha az bulunmuştur. Genel olarak sulama suyu bor değeri artıkça bitki veriminde önce oransal bir artma 1 ppm'den sonra ise oransal bir azalmanın olduğunu görülmektedir. Fasulye bitkisinde $B_{0}$ konusu baz alındığında killi topraklar ise en fazla azalma 5 ppm bor içeren konuda (\%3 8.4) söz konusu olurken \% 26.92 ile en fazla artış 1 ppm bor içeren konuda elde edilmiştir. Genel olarak sulama suyu bor değeri artıkça bitki yaprak sayısında önce oransal bir artma 1 ppm'den sonra ise oransal bir azalmanın olduğu görülmektedir.

Farklı bor düzeylerinde bitki yaş ağırlığı açısından kumlu ve killi toprakların karşılaştırılması

Farklı bor uygulamalarından elde edilen yaş ağırlık değerleri dikkate alındığında kumlu toprakta hiç bor uygulanmamış konuda elde edilen verim değeri (40.99 g saksı $^{-1}$ ), killi toprakta elde edilen verim değerinden (29.00 $\mathrm{g} \mathrm{saks}^{-1}$ ) \% 29 düzeyinde daha düşük bulunmuştur. Bu farklılık oransal olarak diğer konulara da yansımıştır.

Yapılan varyans analizi sonuçlarına göre bitki yaş ağırlığı ortalama değerleri üzerine toprak tekstürü, bor seviyeleri arasındaki farklar istatistiki olarak önemli bulunmuştur $(\mathrm{P}<0.01)$. 
Çizelge 4. Kumlu ve killi topraklara uygulanan bor seviyelerine göre ortalama bitki yaş ve kuru (gr saksı ${ }^{-1}$ ) ağırlıkları ve Tukey grupları

Table 4. Tukey groups according to the plant wet and dry weight ( gr pot $^{-1}$ ) average in the boron levels applied in clay and sandly soils

\begin{tabular}{lllllllll}
\hline Konular (Treatments) & $\mathbf{B}_{\mathbf{0}}$ & $\mathbf{B}_{\mathbf{1}}$ & $\mathbf{B}_{\mathbf{2}}$ & $\mathbf{B}_{\mathbf{3}}$ & $\mathbf{B}_{\mathbf{4}}$ & $\mathbf{B}_{\mathbf{5}}$ & Ortalama (Average) \\
\hline \multirow{2}{*}{$\begin{array}{l}\text { Yaş ağırlık } \\
\text { Wet weight }\end{array}$} & $\begin{array}{l}\text { Kumlu Toprak } \\
\text { (Sandy soil) }\end{array}$ & 40.99 & 41.36 & 43.02 & 41.13 & 38.74 & 29.78 & $39.17 \mathbf{a}$ \\
\cline { 2 - 8 } & $\begin{array}{l}\text { Killi Toprak } \\
\text { (Clay soil) }\end{array}$ & 29.00 & 28.85 & 29.55 & 28.85 & 28.09 & 24.58 & $28.15 \mathbf{~ b}$ \\
\hline $\begin{array}{l}\text { Kuru ağırlık } \\
\text { Dry weight }\end{array}$ & $\begin{array}{l}\text { Kumlu Toprak } \\
\text { (Sandy soil) }\end{array}$ & 21.33 & 21.54 & 21.83 & 21.69 & 20.84 & 19.66 & $21.15 \mathbf{a}$ \\
\cline { 2 - 8 } & $\begin{array}{l}\text { Killi Toprak } \\
\text { (Clay soil) }\end{array}$ & 16.36 & 16.59 & 17.39 & 17.19 & 17.03 & 15.73 & $16.72 \mathbf{b}$ \\
\hline
\end{tabular}

Çizelge 4 incelendiğinde kumlu ve killi topraklardan elde edilen yaş ağırlık değerleri ortalaması sırasıyla 39.17 (gr saksi $^{-1}$ ) ve 28.15 (gr saksı ${ }^{-1}$ ) olarak bulunmuştur. Buna göre rakamsal olarak en yüksek ortalama yaş ağırlık değeri kumlu toprak uygulamasından elde edilmiştir.

Farklı bor seviyeleri uygulanan bitkiler incelendiğinde kumlu topraklardan elde edilen bitki yaş ağılık değerleri killi topraklardan elde edilen bitki yaş ağırlık değerlerine göre \% 31.31 ile \% 17.46 arasında artış göstermiştir. Güneş ve ark. (2000), bor uygulamalarına bağlı olarak mısır çeşitlerinin yaş ve kuru ağırlıklarının önemli ölçüde azaldığını ve bu çeşitlerin bor uygulamalarına bağı olarak yaş ve kuru ağırlıklarında meydana gelen azalmaların nedeninin genotipsel faklılıklar olduğunu belirtmişlerdir.

Ayrıca, Ortaca (2005), ayçiçeği ile yaptığı bir çalışmada artan bor konsantrasyonunun kök yaş ağırlığını azalttığını, yaprak kuru ağırlığı üzerine ise önemli bir etkisinin olmadığı belirtilmiştir. Hasnain ve ark. (2003)'nın mung fasulyesinde yaptıkları çalışmalarında 0-20 ppm arasında bor uyguladıkları fasulyelerin yaprak-kök yaş ve kuru ağırlıklarının 5 ppm'e kadar arttığını daha sonra artan bor konsantrasyonuyla bu değerlerin azaldığını ortaya koymuşlardır. Bu araştırmaların sonuçlarıyla, bu çalışmada elde edilen sonuçlar benzerlik göstermektedir. Bitki kuru ağırlık değerleri açısından ise kumlu topraklarda elde edilen değerler killi topraklardan konulara göre sırasıyla \% 23.30, \% 22.98, \% 20.34, \% 20.75, $\% 18.28$ ve \% 20.03 oranında daha fazla bulunmuştur. Alpaslan ve Güneş (2001), domates ve kabak bitkileri ile yaptıkları çalışmada bor toksisitesinin bitki kuru ağırıklarını azalttığını ortaya koymuşlardır. Lee (2006), acı biber bitkisi ile yaptığı çalışmada benzer sonuçlar elde etmiştir. Soy ve Güneş (2003), bor toksisitesine bağlı olarak domates bitkisinin kuru ağırlı̆ı̆ında azalmalar görüldüğünü belirtmişlerdir. Aynı şekilde araştırma sonuçları Mahalakshmi ve ark., 1995; Lee ve ark., 1996; Khan ve ark., 1999; Hobson ve ark. 2001; Ermiş, 2002; Karabal ve ark., 2003; Sotiropoulos ve ark., 2003; Papadakis ve ark., 2004; Ortaca, 2005; Ardıç, 2006; Ardıç ve ark., 2009'nın elde ettiği sonuçlarla benzerlik göstermektedir.

Ayrıca her iki toprak bünyesinde şahit konusunda ortaya çıkan farklılıkları elimine edebilmek için şahit konudaki değerler baz alınmış ve artan bor düzeylerinde elde edilen değerler şahit konusunda bulunan değerlerden çıkarılarak konulara göre farklıııklar karşılaştırılmıştır (Şekil 7). 
Artan konsantrasyonlarda bor uygulanan fasulye bitkisinin bitki yaş ve kuru ağırlık değerlerinde meydana gelen değişimler kumlu ve killi toprak bünyelerinde birbiriyle benzerlik göstermiştir. Her iki toprak bünyesi için yapılan uygulamalar sonunda yaş ve kuru ağırlıklarda meydana gelen azalmanın en fazla kumlu toprakta olduğu görülmüştür.

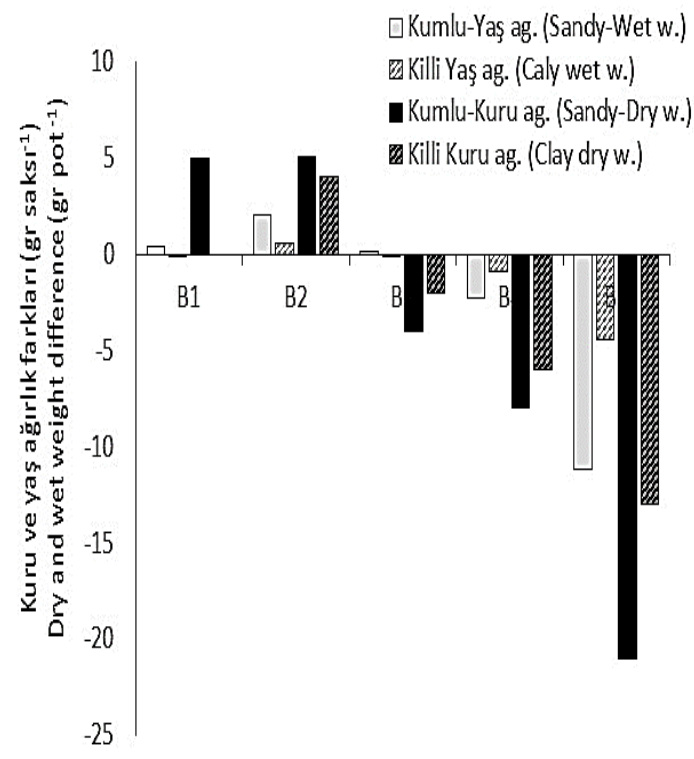

Şekil 7. Bitki yaş ve kuru ağırlıkları ile bor uygulanmayan konu arasındaki fark

Figure 7. Differences between wet and dry weight and treatment of boron not applied

\section{Sonuçlar}

Sonuç olarak, bu çalışmada elde edilen deneysel bulgular ışığında, kumlu ve killi topraklarda yetiştirdiğimiz fasulye bitkisi uygulanan bor konsantrasyonu artışına bağıı olarak, yaş ağırlık, kuru ağırlık ve yaprak sayısı bakımından olumsuz şekilde etkilendiği görülmüştür. Bor'un fasulye bitkisinin ihtiyaç duyduğu miktarın (1 $\mathrm{ppm}$ ) üzerinde uygulanması durumunda (toksik düzeyde) büyüme metabolizmasında metabolik olayları engelleyerek bitkilerde önemli zararlara neden olduğu saptanmıştır. Toprak bünyeleri açısından uygulanan bor seviyelerinin etkileri karşılaştırıldığında fasulye bitkisinin kumlu toprakta daha iyi gelişme göstermesi nedeniyle kumlu toprakta elde edilen değerler killi toprağa göre daha yüksek bulunmuştur.

Ancak toprak bünyelerine göre uygulanan bor düzeylerinin şahit konusunda elde edilen değerlerle olan oransal farkları incelendiğinde kumlu toprağın bor toksikliğinin killi toprağa göre daha yüksek olduğu bulunmuştur. Her toprak bünyesi için bitkinin bor eşik değeri 1 ppm olarak saptanmıştır. Eşik değerini aşan yüksek borlu suların kumlu topraklar yerine killi topraklarda kullanılması önerilebilir.

\section{Ekler}

$\mathrm{Bu}$ makale Yüksek Lisans Tezinden üretilmiştir. Çalışma, Süleyman Demirel Üniversitesi Bilimsel Araştırma Projeleri Koordinasyon Birimi tarafından 3396-YL1-12 nolu proje ile desteklenmiştir.

\section{Kaynaklar}

Alpaslan, M., Güneş A., 2001. Interactive Effects of Boron and Salinity Stress on the Growth, Membrane Permeability and Mineral Composition of Tomato and Cucumber Plants, Plant and Soil, 236: 123128.

Ardıç, M., 2006. Bor Toksisitesinin Nohut (Cicer arietinum L.) Bitkisinde Bazı Fizyolojik ve Biyokimyasal Özellikler Üzerindeki Etkileri. Osmangazi Üniversitesi, Fen Bilimleri Enstitüsü, Doktora Tezi, 95-98, Eskişehir.

Ardıç, M., Sekmen A.H., Türkan İ., Tokur S., Özdemir F., 2009. The Effects of Boron Toxicity on Root Antioxidant Systems of Two Chickpea (Cicer arietinum L.) Cultivars. Plant Soil, 314: 99-108.

Ayyıldız, M., 1992. Sulama Suyu Kalitesi ve Tuzluluk Problemleri. A.Ü. Ziraat Fakültesi Yayınları, 344-346, Ankara. 
Bhatnager, R. S., Attri, S. C.; Mathur, G. S., Chaudhary, R. S., 1979. Boron adsorption equilibrium in soils. Annals of Arid Zone. 18: 86-95.

Demirtaş, A., 2005. Bitkide Bor Ve Etkileri. Atatürk Üniversitesi Ziraat Fakültesi Dergisi, 36 (2): 217-225.

Elrashidi, M.A., O'Connor, G.A., 1982. Boron sorption and desorption in soils. Soil Science Society of America Journal. 46: 2731.

Ermiş, İ., 2002. Bazı Arpa Çeşitlerinin Çimlenme Yüzdesi ve Antioksidant Enzim Düzeylerine Bor Stresinin Etkisi. Ege Üniversitesi, Fen Bilimleri Enstitüsü, Yüksek Lisans Tezi, 6567, İzmir.

Güneş, A., Alpaslan, M., İnal, A., 2000. Bitki besleme ve gübreleme, Ankara Üniversitesi Ziraat Fakültesi Yayın No:1514, Ders Kitabı No:467, Ankara Üniversitesi Basımevi, Ankara.

Güngör, Y., Erözel, A. Z., 1994. Drenaj ve Arazi Islahı. Ankara Üniversitesi Ziraat Fakültesi Yayınları No:1341: 232-235, Ankara.

Hasnain, A., Mahmood, S., Akhtar, S., Malik, S.A., Bashir, N., 2011. Tolerance and Toxicity Levels of Boron in Mung Bean (Vigna Radiata (L.) Wilczek) Cultivars at Early Growth Stages. Pakistan Journal of Botony, 43(2): 1119-1125.

Hobson, K.,B., Seymour, L.R., Armstrong, RD., Connor, D., Brand, J.D., Materne, M., 2001. Improving the Adaptation, Profitability and Reliability of Pulses Growing on Hostile Alkaline Subsoils. Proceedings of the 10th Australian Argonomy Conference, Hobarts.

Karabal, E., Yücel, M., Öktem, H.A., 2003. Antioxidant Responses of Tolerant and Sensitive Barley Cultivars to Boron Toxicity. Plant Science, 164: 925-933.

Khan, N., Young, K.I., Gartrell, J.N., 1999. Research Officers, Borc Toxicity in Barley. Division of Plan Research, Agriculture Western Australia, Farmnot, 85.

Lee, C.W., Choi, J.M., Pak, C.H., 1996. Micronutrient Toxicity Seed Genanium (Pelargonium xhantum Boiley). Journal of American Society for Horticultural Science, 121 (1): 7-82.
Lee, S.K.D., 2006. Hot Pepper Response to Interactive Effects of Salinity and Boron. Plant Soil Environment, 52: 227-233.

Mahalakshmi, U. Yau, P.K., Ryan, J., Peacock, J.M., 1995. Boron Toxicity in Barley (Hordeum Vulgare L.) Seedlings in Relation to Soil Tempetature. Plant Soil, 177 (2): 151-156.

Mezuman, U., Keren, R., 1981. Boron adsorption by soils using a phenomenological adsorption equation. Soil Science Society of America Journal. 45: 722-726.

Ortaca, Ş., 2005. Borun Ayçiçeği Bitkisinde Vejetatif Büyüme, Pigment, Protein Miktarı ve Protein Profili Üzerine Etkileri. Dumlupınar Üniversitesi Fen Bilimleri Enstitüsü, Yüksek Lisans Tezi, 52-53, Kütahya.

Papadakis, F., Dimassi, K.N., Bosabalidis, A.M., Therios, N., Patakas, A., Giannakoula, A., 2004. Boron Toxicity in Clementine Mandarin Plants Grafted on Two Nootstocks. Plant Science, 166: 539-547.

Sotiropoulos, T.E., Therios, N., Dimassi, K. N., 2003. Boron Toxicity in Kiwifruit (Actinidia Deliciosa L.), Treated with Nitrate, Amnionium, and A Mixyure of Both. Journal of Plant Nutrition and Soil Science, 166: 529-532.

Soy, M., Güneş, A., 2003. Fosforun Domates (Lycopersicon esculentum L.) Bitkisinde Bor Toksisitesini Önlemede Etkisi. Tarım Bilimleri Dergisi, A. Ü. Ziraat Fakültesi, No. 9(3):273-277.

Tüzüner, A., 1990. Toprak ve Su Analiz Laboratuvarları El Kitabı. Tarım ve Köyişleri Bakanlığı, Köy Hizmetleri Genel Müdürlüğü Yayını. 11-12.

Wear, J. I., Patterson, R. M., 1962. Effect of soil $\mathrm{pH}$ and texture on the availability of water-soluble boron in the soil. Soil Science Society of America Proceedings. 26:344-346.

Wild, A., Mazaheri, A., 1979. Prediction of the leaching rate of boric acid under field conditions. Geoderma. 22:127-36.

Yurtsever, N., 1984. Deneysel İstatistik Metotları. Toprak ve Gübre Araştırma Enst. Müdürlüğü Yayınları No. 121/56. 